\title{
Analysis of Factors Related to Employee Performance at the Aceh Provincial Health Office in 2019
}

\author{
Teuku Mukhlis ${ }^{1}$, Nizam Ismail ${ }^{2}$, Said Usman ${ }^{3}$, Irwan Saputra ${ }^{4}$, Hajjul Kamil ${ }^{5}$ \\ 1,2,3,4,5 Faculty of Medicine, Universitas Syiah Kuala, Indonesia \\ Teukumukhlis72@gmail.com,Nizamismail@gmail.com,saidusman@unsyiah.ac.id,Iwan.bulba@gmail.com \\ hajjul.kamil@unsyiah.ac.id
}

\begin{abstract}
The performance of the Aceh Provincial Health Office is closely related to the attitudes of its employees towards their own work, work situation, cooperation between leaders and fellow employees. Actualized performance by employees is also supported by several factors Objective: analyzing factors related to the performance of Aceh Provincial Health Office employees in 2019 Research Method: This type of research is observational using a cross sectional design. Statistical analysis using multiple regression Results: there is a impact of compensation $\left(X_{1}\right)$, leadership style $\left(X_{2}\right)$ work discipline $\left(X_{3}\right)$ and application of sanctions $\left(X_{4}\right)$ with the performance of the Aceh Provincial Health Office Staff and Conclusion: factors that influence performance are compensation, leadership style work discipline and the imposition of sanctions.
\end{abstract}

\section{Keywords}

compensation; leadership style; work discipline; application of sanctions, performance

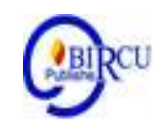

\section{Introduction}

Employees are one of the most important factors of production in an agency, without them how difficult it is for the agency to achieve its goals, it is they who determine the ups and downs of an agency, by having skilled workforce with high motivation the agency already has very expensive assets, because basically humans are the subject and object of development which is a very important factor, especially improving the quality of human resources is a top priority. The Health Service is an agency engaged in the field of public health services, where the successful implementation of tasks and responsibilities within the agency depends on the performance of existing employees in these agencies, the importance of the performance of existing employees at the Health Office is very influential on the implementation of the agency's goals, namely to improve services to the community, especially in the process of supervision and guidance to the needs of information and health services (Sutrisno, 2016)

The work discipline of Aceh Provincial Health Office employees can be seen from the level of attendance and on time to come to the office. This can be seen from the level of absenteeism achieved while motivation is an encouragement from within the employee to achieve a goal. An employee will do a good job if there is encouragement from within him. Encouragement will arise if someone has a need to be fulfilled, for example the need to achieve success, the need to be able to socialize with other employees and the need to gain power. Not all employees feel motivated just because the material, in addition to money and goods giving attention from subordinates and appreciation for employees who excel will affect the level of employee motivation. This can be an incentive for employees to work better and can improve performance and have a sense of responsibility for their work (DinkesAceh, 2018).

Performance is the result of work that can be obtained by workers, a management process or an organization as a whole, where the results of the work can be demonstrated in 
real terms both in terms of quality and quantity (Sedarmayanti, 2016). Some researchers regarding the performance of health service employees have been conducted by researchers, including research conducted at the East Kutai Health Office which concluded that the influence of incentive variables $\left(\mathrm{X}_{1}\right)$, competence $\left(\mathrm{X}_{2}\right)$, motivation $\left(\mathrm{X}_{3}\right)$, work discipline $\left(\mathrm{X}_{4}\right)$, environment employment $\left(\mathrm{X}_{5}\right)$, social security $\left(\mathrm{X}_{6}\right)$, nutrition and health $\left(\mathrm{X}_{7}\right)$ on the performance of Health Service employees in Sangatta are relatively strong. The influence explained by the compensation variable $\left(\mathrm{X}_{1}\right)$, competence $\left(\mathrm{X}_{2}\right)$, motivation $\left(\mathrm{X}_{3}\right)$, work discipline $\left(\mathrm{X}_{4}\right)$, work environment $\left(\mathrm{X}_{5}\right)$, Social security $\left(\mathrm{X}_{6}\right)$, nutrition and health $\left(\mathrm{X}_{7}\right)$ together on performance employees at $75.5 \%$, the rest is explained by other variables not yet included in the research model. Evidenced by the results of the F test and significance which shows a significance value of 0,000 smaller with an alpha level of 0.05 , it is concluded that the first hypothesis stating the intellectually variable $\left(\mathrm{X}_{1}\right)$, competence $\left(\mathrm{X}_{2}\right)$, motivation $(\mathrm{X} 3)$, work discipline $\left(\mathrm{X}_{4}\right)$, work environment $\left(\mathrm{X}_{5}\right)$, social security $\left(\mathrm{X}_{6}\right)$, nutrition and health $\left(\mathrm{X}_{7}\right)$ have an effect on the performance of Sangatta Health Service employees proven correct or the first hypothesis is accepted (Rizki, 2016).

\section{Review of Literature}

\subsection{Employee Performance}

Performance as the appearance of the work of personnel both in quantity and quality in an organization. Performance can be the appearance of individual or group work personnel. The appearance of the work is not limited to personnel who hold functional or structural positions, but also to the entire range of personnel in the organization (Ilyas, 2012).

Employee performance is closely related to the results of one's work in an organization or company. The results of the work can involve quality, quantity, and timeliness, but performance evaluation in a company's organization is key in employee development. Performance evaluation is in principle a manifestation ofan employee's performance appraisal form (Irfansyah in Kuswati, 2020)

Performance is the work that can be achieved by a person or group of people in a company in accordance with their respective authorities and responsibilities in an effort to achieve the company's goals illegally, does not violate the law and does not conflict with morals and ethics. According to Ilyas (2012) performance is a record of the output of results in a function of the job position by all work activities in a certain period of time. In general, what is meant by performance (Performance $=\mathrm{P}$ ) is the result of interaction between motivation $(\mathrm{M})$ and ability (Ability $=\mathrm{A}$ ), which in attribution theory is formulated with $\mathrm{P}=\mathrm{f}$ (M x A).

In this study the notion of performance used is the definition of performance according to Ilyas (2012), namely the appearance of the work of personnel both in quantity and quality in an organization. Each employee has different work results, another understanding states that performance (work performance) is the work of quality and quantity achieved by an employee in carrying out their duties in accordance with the responsibilities given to him. Performance is the willingness of a person or group of people to carry out activities or perfect them in accordance with their responsibilities with the results as expected (Riniwati, 2011).

\subsection{Relationship between Compensation and Performance}

The workers do their job in the company one of them is because they expect compensation or compensation from the company. In general, the compensation given will not be equalized for all employees or workers in the company. This is what sometimes causes 
employees to feel that they are not enough with the compensation given to them. So that often strikes occur because of compensation issues. Compensation is one of the motivations for the employees themselves to improve their performance. So employees compete to increase their creativity for the company. For those who can continue to increase their creativity, the compensation will be increased along with the increase in the employee's performance and creativity. But for those who have not been able to increase their creativity, compensation will not be given any increase so that it sometimes results in frustration for the employee itself and ultimately the employee's performance decreases. so the greater the compensation given by the company to its employees, the higher the efforts of the employees to improve their performance. And vice versa, if the compensation given to employees is lower even below the average stipulated in the law, then the lower the performance of employees given to the company because they will feel the compensation provided both financial and non-financial compensation is not comparable with that they give to the company. And this can cause the employee to move to another company. Meanwhile, if compensation is increased, the employee will definitely continue to provide improved performance in the company without moving to another company (Moeheriono, 2014).

\section{a. Relationship between Leadership Style and Performance}

Leadership is an effort that uses a style and influences and does not force to motivate individuals to achieve goals. The definition of leadership implies that leadership involves users of influence and that all related can involve leadership. The second element in the definition involves the importance of being an agent for change capable of influencing and the performance of followers and focusing on achieving goals. Performance is a function of the ability of workers to accept work goals, the level of achievement of goals and the interaction between the goals and abilities of workers (Ajeng Kartika, 2014).

With this definition it can be said that employees play an important role in carrying out all activities of the company in order to grow and develop to maintain the survival of the company. To create reliable human resources requires good management so that Employee Performance is more optimal. The achievement of company goals is influenced by the performance of the company's own Employees. Thus the company needs potential and quality human resources, both in terms of leaders and employees in the pattern of duties, responsibilities, efficient in accordance with regulations and supervision that is a determinant of achieving company goals. According to the analysis the leaders most effectively match their leadership style to the situation, including the work style they like and personality traits, as well as the nature of the task and the group. Likewise with motivation, the relationship between motivation and performance is positive, increasing motivation will result in more effort and work performance or performance

\section{b. Relationship of Discipline with Performance}

There are many factors that affect employee performance, one of the many factors is work discipline because without the discipline, all activities carried out will bring unsatisfactory results and not in accordance with expectations. This can result in not achieving the company's goals and objectives so that it can inhibit the company's growth. Discipline is a process used to deal with performance problems (Afianto, 2017).

The results of research on the effect of work discipline and work motivation on the performance of employees of the Ros In Yogyakarta Hotel Work Discipline has a positive and significant effect on the performance of employees of the Ros In Yogyakarta Hotel. This is evidenced by the results of the regression calculations obtained values of $(\beta) 0.340(p$ $<0.05 ; \mathrm{p}=0,000)($ Sanjaya, 2015). 


\section{c. Relationship between Application of Sanctions and Performance}

Competence explains what employees do at work at various levels and breaks down the standards of each level, identifies the characteristics of knowledge and skills needed by individuals that enable them to carry out their duties and responsibilities effectively so as to achieve professional quality standards at work and produce good performance ( Pattiasina, 2014).

Employee competency can be achieved by providing training to employees in accordance with their work needs and organizational goals. An employee has high competence if the employee has work experience, educational background that supports the profession, has expertise / knowledge, and has skills.

Another study conducted at the Yogyakarta City Licensing Department concluded that there was a positive and significant effect of competence on employee performance at the Yogyakarta City Licensing Service $(\beta=0.460 ; p=0.000 ; R 2=20.7 \%)$ (Riyanda, 2017)

Penal sanctions play an important role in maintaining employee discipline. With sanctions increasingly severe penalties, employees will be increasingly afraid of violating organizational rules, attitudes and disciplinary behavior of employees will be reduced. Severe or mild witnesses of the punishment to be applied also influence the merits of employee discipline. Penalty sanctions must be determined based on logical, reasonable, and clearly informed information to all employees (Rahman, 2016).

\section{Research Method}

This research is a quantitative study, using a cross sectional study design, is a research design by observing at the same time. The quantitative approach emphasizes the existence of variables as research objects and these variables are defined in the form of the operationalization of each variable (Sriyanto, 2010). Quantitative research is a method for testing certain theories by examining the relationship between variables. This is intended to obtain factors related to performance at the Aceh Provincial Health Office. This research was conducted in June 2020 at the Aceh Provincial Health Office.

The population in this study were all employees of the Provincial Health Office in Aceh totaling 389 employees from the Health Office, starting from the lowest level to the Head of Office. The sample in this study was determined by simple random sampling technique by determining the sample size in advance using the Slovin equation.

$$
n=\frac{N}{1+N e^{2}}
$$

Where

$n$ : number of samples

$\mathrm{N}$ : total population

e: error tolerance limit

$$
\begin{gathered}
n=\frac{N}{1+N e^{2}} \\
n=\frac{389}{1+389(0,1)^{2}} \\
n=\frac{389}{1+555(0,01)}
\end{gathered}
$$




$$
\begin{gathered}
n=\frac{389}{1+38.9} \\
n=\frac{389}{1+3,89} \\
n=\frac{389}{4,89} \\
n=188,55 \approx 189
\end{gathered}
$$

The variables in this study consisted of independent variables and dependent variables.

\begin{tabular}{|c|c|c|c|c|c|}
\hline No Variable & $\begin{array}{l}\text { Operational } \\
\text { definition }\end{array}$ & $\begin{array}{l}\text { The way to } \\
\text { Measure }\end{array}$ & $\begin{array}{c}\text { Measuring } \\
\text { instrument }\end{array}$ & $\begin{array}{l}\text { Measuring } \\
\text { Scale }\end{array}$ & $\begin{array}{l}\text { Measure } \\
\text { Results }\end{array}$ \\
\hline \multicolumn{6}{|l|}{ Dependent } \\
\hline $\begin{array}{ll}1 & \text { The } \\
\text { performance }\end{array}$ & $\begin{array}{l}\text { Maximum work } \\
\text { results of the } \\
\text { Health Service } \\
\text { employees based } \\
\text { on the rules and } \\
\text { standards in force } \\
\text { at the Health } \\
\text { Service }\end{array}$ & $\begin{array}{l}\text { Spread } \\
\text { The } \\
\text { questionnaire } \\
\text { uses a Likert } \\
\text { scale } \\
\text { Strongly } \\
\text { Agree to } \\
\text { Very } \\
\text { Disagree (5 } \\
\text { to 1) }\end{array}$ & Questionnaire & ordinal & $\begin{array}{l}\text { Good } \\
\text { Less }\end{array}$ \\
\hline \multicolumn{6}{|l|}{ Independent } \\
\hline $\begin{array}{l}2 \text { Compensation } \\
\left(\mathrm{X}_{1}\right)\end{array}$ & $\begin{array}{l}\text { rewards received } \\
\text { by employees } \\
\text { because of the } \\
\text { work they provide }\end{array}$ & $\begin{array}{l}\text { Spread } \\
\text { Right } \\
\text { Questionnai } \\
\text { re }\end{array}$ & Questionnaire & ordinal & $\begin{array}{l}\text { uai } \\
\text { ak sesuai }\end{array}$ \\
\hline
\end{tabular}
The independent variable is compensation $\left(\mathrm{X}_{1}\right)$, leadership style $\left(\mathrm{X}_{2}\right)$, work discipline $\left(\mathrm{X}_{3}\right)$, application of sanctions $\left(\mathrm{X}_{4}\right)$, while the dependent variable in this case is performance $(\mathrm{Y})$.

Table 1. Operational Research Definitions

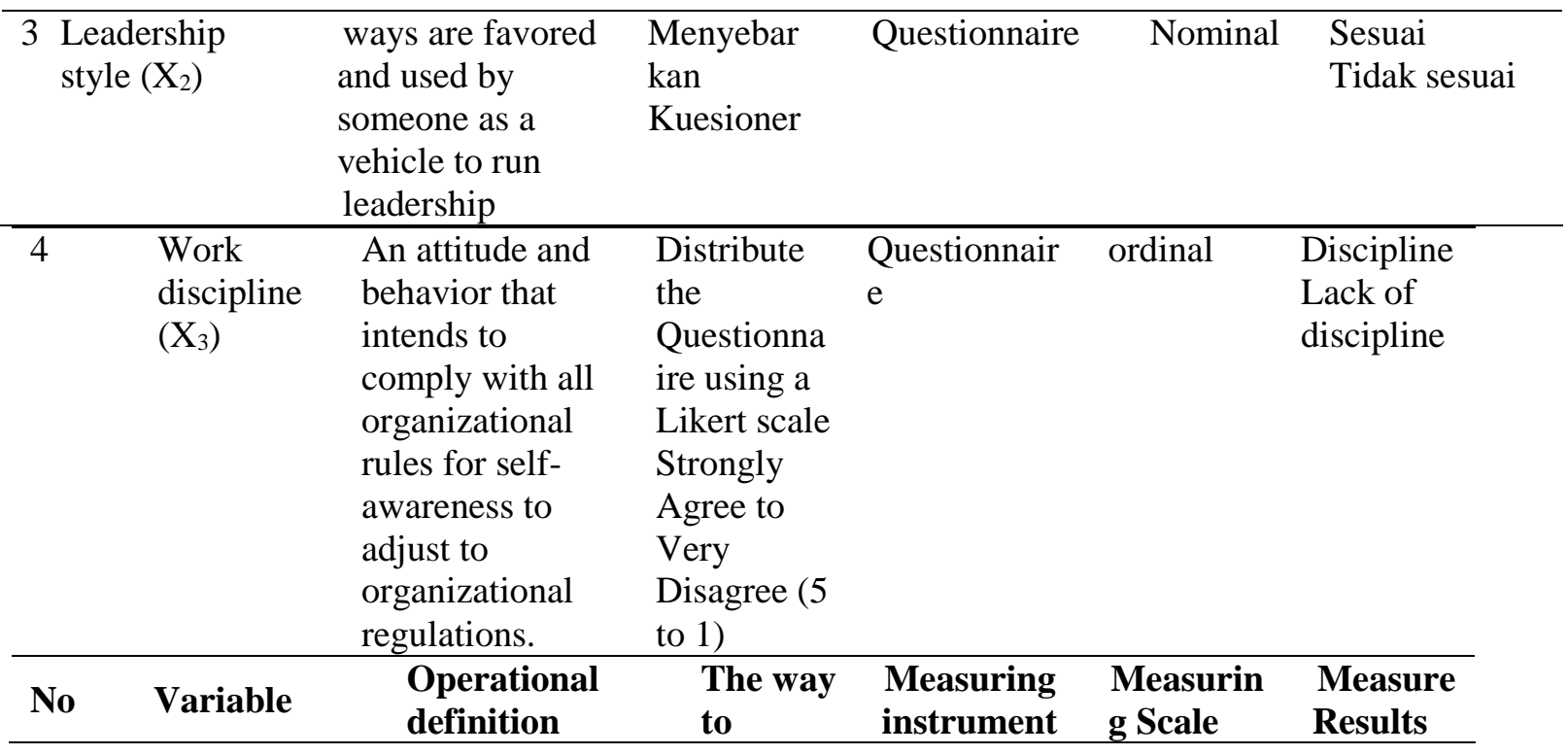




\begin{tabular}{|c|c|c|c|c|c|c|}
\hline \multicolumn{7}{|c|}{ Measure } \\
\hline \multicolumn{7}{|c|}{ Variable } \\
\hline 5 & $\begin{array}{l}\text { Application } \\
\text { of sanctions } \\
\left(\mathrm{X}_{4}\right)\end{array}$ & $\begin{array}{l}\text { Efforts to } \\
\text { implement } \\
\text { written and } \\
\text { unwritten } \\
\text { sanctions in } \\
\text { work-related } \\
\text { activities }\end{array}$ & $\begin{array}{l}\text { Distribute } \\
\text { the } \\
\text { Questionna } \\
\text { ire using a } \\
\text { Likert scale } \\
\text { Strongly } \\
\text { Agree to } \\
\text { Very } \\
\text { Disagree (5 } \\
\text { to } 1 \text { ) }\end{array}$ & Questionnaire & ordinal & $\begin{array}{l}\text { Exist } \\
\text { No }\end{array}$ \\
\hline
\end{tabular}

Univariate analysis to get a picture of the frequency distribution or the magnitude of the proportion of the influence factors found both in cases and controls on each variable studied, the data to be obtained in the form of frequency and distribution. This data will be described in the form of tables and graphs of all variables studied, both independent variables (dependent) and dependent variables (Dependent). Univariate analysis using computer devices.

The analysis used to see the relationship between the variables studied using the chi square test with the following conditions:

1. If the table is $2 \times 2$, and there is no value of $\mathrm{E}<5$, the test used should be "Continuity Correction"

2. If the table is $2 \times 2$, and there is an E value $<5$ then the test used is the "Fisher's Exact Test"

3. If the table is more than $2 \times 2$, the "Pearson Chi Square" test will be used

Multivariate analysis is to see the relationship between the variables studied. The stages in the multivariate analysis process include:

1. Include candidate variables in the multivariate logistic regression analysis process by selecting an independent variable that has a $\mathrm{p}$ value $<0.25$.

2. Conduct an analysis of all independent variables included in the modeling, by issuing the independent variable that has the largest $\mathrm{p}$ value, so that the initial model is obtained with the determinant variables that have a value of $p<0.05$.

3. Based on multivariate test results that have a value of $p<0.05$ is the final model of determining risk factors related to the performance of health workers

To find out the magnitude of the relationship between the independent variables (X) to the dependent variable $(\mathrm{Y})$ or to determine the extent to which the independent variables $(\mathrm{X})$ affect the dependent variable (Y) and besides that because it uses more than one independent variable, the model The analysis used is a multiple logistic regression model.

The analysis technique used in this study is to use quantitative analysis. Data were analyzed using multiple regression analysis models with the help of the SPSS 20 program with the following steps:

1. Determine the regression coefficient for each independent variable multiple correlations $(\mathrm{R})$ for each independent variable $(\mathrm{X})$ against the dependent variable $(\mathrm{Y})$.

2. Partial correlation (r) for each independent variable (X)

3. $F$ test results and $t$ test

4. The probability level of each variable If $\mathrm{R} 2$ results close to 0 (zero), then the effect is weak. 
In general, it can be said that the magnitude of a coefficient of determination (R2) is between 0 and 1 or $0<\mathrm{R} 2<1$. The coefficient of determination is one of the statistical values that can be used to determine whether there is a relationship between two variables.

To test whether the first hypothesis proposed is rejected or accepted, it is carried out through the F test as follows:

1. Testing the first hypothesis using the $F$ test which is used to determine whether the simultaneous regression coefficient of an independent variable has an influence or not on the dependent variable. Hypothesis testing is done with a confidence level of $95 \%(œ=$ 5\%). Hypothesis Criteria:

Ho: b1: b2: b3: b4 = 0

Ha: b1: b2: b3: b4 \# 0

If the calculated $\mathrm{F}$ value is greater than the $\mathrm{F}$ Table, then the hypothesis $0(\mathrm{Ho})$ is rejected and the alternative hypothesis $(\mathrm{Ha})$ is accepted.

2. Submission of the second hypothesis is done by t test, which is to test the effect of independent variables separately on the dependent variables. Hypothesis Criteria:

Ho: $\mathrm{b} 1=0$

Ha: b1 \# 0

If the value of $t$ Calculate is greater than t Table, then the hypothesis $0(\mathrm{Ho})$ is rejected and the alternative hypothesis (Ha) is accepted. To see the dominant influence derived from the $t$ test by looking at the standard value of the largest Beta coefficient.

3. Classical Assumptions Testing Testing of classical assumptions is testing with assumptions that underlie the implementation of multiple linear regression so that the results can be relied on, it is necessary to test multicollinearity, heteroscedasticity and autocorrelation.

a. Multicollinearity Test According to Ghozali (2015), multicollinearity test aims to determine whether the regression model found a correlation between independent variables (independent). A good regression model should not occur correlation between independent variables. To detect the occurrence of multicollinearity can be seen based on the results of the variance inflation factor (VIF). The cutoff values commonly used to show the presence of multicollinearity are tolerance values $<0.10$ or equal to VIF values> 10 .

b. Heteroscedasticity Test According to Ghozali (2015) heteroscedasticity test is used to test in the regression model that there is an inequality of variance from the residuals of one observation to another. To detect the presence or absence of heteroskedsticity that is to see the spread of the residual variant.

c. Autocorrelation Test Autocorrelation is a symptom of a correlation between all variables from a series of observations arranged in chronological order, as well as a correlation between disturbance variables. To find out the presence or absence of autocorrelation symptoms, a routine or serial test is used to calculate the estimated residuals in a regression analysis. This symptom test is very necessary in experimental research. While this research is in the form of post-facto so that here it is not proven in detail. Approach to the autocorrelation problem is carried out using the Durbin-Watson test (DW Test). According to Algifari in his book Inductive Statistics (2010), to adopt the existence of a regression model is done by the Durbin Watson test. 


\section{Result and Discussion}

The establishment of the Aceh Provincial Health Service is a service that aims to increase awareness, willingness and ability to live a healthy life for everyone in order to achieve optimal health status. Led by the head of the office which is located below and is responsible to the Governor through the Regional Secretary. The Aceh Provincial Health Office has main tasks including, the Head of Service in carrying out tasks based on policies stipulated by the Governor, submitting task implementation reports to the Governor on a scale through the Regional Secretary and carrying out general tasks of government and development in the field of cleanliness and beauty. Based on data from the Aceh Provincial Health Office up to July 13, 2020 there were 382 employees, with details based on education as follows:

Table 2. Distribution of Aceh Provincial Health Service Staff by Education Level in 2020

\begin{tabular}{llll}
\hline \multirow{2}{*}{ No } & \multirow{2}{*}{ Education } & \multicolumn{2}{l}{ Total } \\
\cline { 3 - 4 } & & $\mathbf{f}$ & $\mathbf{\%}$ \\
\hline 1 & Profession & 6 & 1,6 \\
2 & Level 3 (S3) & 3 & 0,8 \\
3 & Level 2 (S2) & 103 & 27,0 \\
4 & Level 1 (S1) & 145 & 38,0 \\
5 & Diploma IV (DIV) & 4 & 1,0 \\
6 & Diploma III (DIII) & 45 & 11,8 \\
7 & Diploma I (DI) & 3 & 0,8 \\
8 & Snior High School (SLTA) & 73 & 19,1 \\
\hline & Total & $\mathbf{3 8 2}$ & 100 \\
\hline
\end{tabular}

Source: Aceh Provincial Health Office, 2020

Table 2 shows that the majority of employees of the Aceh Provincial Health Service have a Bachelor's degree education of $38.0 \%$ and only $1.6 \%$ have a certain professional education.

Table 3. Distribution of Staff of the Aceh Provincial Health Service by Gender in 2020

\begin{tabular}{lllll}
\hline \multirow{2}{*}{ No } & \multirow{2}{*}{ Gender } & \multicolumn{2}{l}{ Total } \\
\cline { 3 - 4 } & & $\mathbf{f}$ & $\mathbf{\%}$ \\
\hline 1 & Male & 153 & 40,1 \\
2 & Female & 229 & 59,9 \\
\hline & Total & $\mathbf{3 8 2}$ & 100 \\
\hline
\end{tabular}

Source: Aceh Provincial Health Office, 2020

Table 3 shows that the majority of employees of the Aceh Provincial Health Office were female, namely $59.9 \%$. 


\subsection{Univariate Analysis}

1. Characteristics of Respondents

Table 4. Distribution of Frequency of Respondents Based on Characteristics of Health Officers in Aceh Province

\begin{tabular}{|c|c|c|}
\hline No & Age & Frequency (\%) \\
\hline 2 & $21-30$ Year & $19(10,1)$ \\
\hline 3 & $31-40$ Year & $48(25,4)$ \\
\hline 4 & $41-50$ Year & $86(45,5)$ \\
\hline 5 & $51-60$ Year & $27(14,3)$ \\
\hline No & Gender & Frequency (\%) \\
\hline 1 & Female & $117(61,9)$ \\
\hline 2 & Male & $72(38,1)$ \\
\hline No & Last education & Frequency (\%) \\
\hline 1 & Senior High School & $6(3,2)$ \\
\hline 2 & D III/ D IV & $15(7,9)$ \\
\hline 3 & S1 & $80(42,3)$ \\
\hline 4 & S2 & $88(46,6)$ \\
\hline No & Marital status & Frequency (\%) \\
\hline 1 & Unmerried & $15(7,9)$ \\
\hline 2 & Merried & $160(84,7)$ \\
\hline \multirow[t]{2}{*}{3} & Widower/widow & $14(7,4)$ \\
\hline & Total & $189(100)$ \\
\hline No & Position & Frequency (\%) \\
\hline 1 & Staff & $64(33,9)$ \\
\hline 2 & Esselon IV/b & $39(20,6)$ \\
\hline 3 & Esselon IV/a & $66(34,9)$ \\
\hline 4 & Esselon III/b & $14(7,4)$ \\
\hline 5 & Esselon III/a & $6(3,2)$ \\
\hline No & Grade Group & Frequency $(\%)$ \\
\hline 1 & Gol I & $5(2,6)$ \\
\hline 2 & Gol II & $59(31,2)$ \\
\hline 3 & Gol III & $20(10,6)$ \\
\hline 4 & Gol IV & $105(55,5)$ \\
\hline No & Length of work & Frequency $(\%)$ \\
\hline 1 & $<10$ Year & $12(6,3)$ \\
\hline 2 & 11-20 Year & $54(28,6)$ \\
\hline 3 & 21-30 Year & $98(51,9)$ \\
\hline 4 & 31-40 Year & $25(13,2)$ \\
\hline & Total & $189(100)$ \\
\hline
\end{tabular}

Source: Primary Data (processed), 2020

Table 4 shows that $45.5 \%$ of Aceh Provincial Health Office employees were 41-50 years old, and were male $(61.9 \%), 46.6 \%$ had a postgraduate degree, were married $(84.7 \%)$ and held positions echelon IV / a (34.9\%), based on rank, the majority of respondents are in group IV, namely 105 people (55.5\%) with a maximum working period of 21-30 years, namely 98 people (51.9\%). 


\section{Compensation $(X \neg 1)$}

The compensation variable is measured using a questionnaire with the answer choices strongly agree (5), agree (4), neutral (3), disagree (2) and strongly disagree (1). The results of the compensation variable tabulation can be seen in the following table:

Table 5. Distribution of Frequency of Respondents by Compensation in Aceh Provincial Health Office in 2020

\begin{tabular}{llll}
\hline \multirow{2}{*}{ No } & \multirow{2}{*}{ Compensation } & Total & \\
\cline { 3 - 4 } & & $\mathbf{f}$ & $\mathbf{\%}$ \\
\hline 1 & Unsuitable & 105 & 55,6 \\
2 & Suitable & 84 & 44,4 \\
\hline & Total & $\mathbf{1 8 9}$ & $\mathbf{1 0 0}$ \\
\hline
\end{tabular}

Source: Primary Data (processed), 2020

Table 5 shows that 55.6\% of employees at the Aceh Besar Provincial Health Office stated that the compensation provided was not appropriate.

\section{Leadership Style $\left(\mathrm{X}_{2}\right)$}

Leadership style variables are measured using a questionnaire with answer choices strongly agree (5), agree (4), neutral (3), disagree (2) and strongly disagree (1). The results of the compensation variable tabulation can be seen in the following table:

Table 6. Distribution of Frequency of Respondents by Leadership Style in Aceh Provincial Health Office 2020

\begin{tabular}{llll}
\hline \multirow{2}{*}{ No } & \multirow{2}{*}{ Leadership Style } & Total & \\
\cline { 3 - 4 } & & $\mathbf{f}$ & $\mathbf{\%}$ \\
\hline 1 & Unsuitable & 51 & 27,0 \\
2 & Suitable & 138 & 73,0 \\
\hline & Total & $\mathbf{1 8 9}$ & $\mathbf{1 0 0}$ \\
\hline
\end{tabular}

Source: Primary Data (processed), 2020

Table 6 shows that $73.0 \%$ of employees at the Aceh Besar Provincial Health Office stated that the current leadership style was appropriate.

\section{Work Discipline $\left(\mathrm{X}_{3}\right)$}

Work disciplines variables are measured using a questionnaire with answer choices strongly agree (5), agree (4), neutral (3), disagree (2) and strongly disagree (1). The results of the compensation variable tabulation can be seen in the following table:

Table 7. Distribution of Frequency of Respondents by Work Discipline in the Aceh Provincial Health Office in 2020

\begin{tabular}{llll}
\hline \multirow{2}{*}{ No } & \multirow{2}{*}{ Work Discipline } & Total & \\
\cline { 3 - 4 } & & $\mathbf{f}$ & $\mathbf{\%}$ \\
\hline 1 & Less Discipline & 63 & 33,3 \\
2 & Discipline & 126 & 66,7 \\
& Total & $\mathbf{1 8 9}$ & $\mathbf{1 0 0}$ \\
\hline
\end{tabular}

Source: Primary Data (processed), 2020 
Table 7 shows that the majority of respondents were disciplined in carrying out their duties in the Aceh Provincial Health Office (66.7\%)

\section{Application of Sanctions $\left(\mathrm{X}_{4}\right)$}

The variable implementation of sanctions is measured using a questionnaire with answer choices strongly agree (5), agree (4), neutral (3), disagree (2) and strongly disagree (1). The results of the compensation variable tabulation can be seen in the following table:

Table 8. Distribution of Frequency of Respondents Based on the Application of Sanctions in Aceh Provincial Health Office 2020

\begin{tabular}{llll}
\hline \multirow{2}{*}{ No } & \multirow{2}{*}{ Application of Sanctions } & Total & \\
\cline { 3 - 4 } & & $\mathbf{f}$ & $\mathbf{\%}$ \\
\hline 1 & There is no & 58 & 30,7 \\
& There is & 131 & 69,3 \\
& Total & $\mathbf{1 8 9}$ & $\mathbf{1 0 0}$ \\
\hline
\end{tabular}

Source: Primary Data (processed), 2020

Table 8 shows that the majority of respondents stated that sanctions were applied in the Aceh Provincial Health Office (69.3\%).

\section{Performance (Y)}

The variable implementation of sanctions is measured using a questionnaire with answer choices strongly agree (5), agree (4), neutral (3), disagree (2) and strongly disagree (1). The results of the compensation variable tabulation can be seen in the following table:

Table 9. Distribution of Frequency of Respondents by Performance in Aceh Provincial Health Office in 2020

\begin{tabular}{|c|c|c|c|}
\hline \multirow{2}{*}{ No } & \multirow{2}{*}{ The performance } & \multicolumn{2}{|c|}{ Total } \\
\hline & & f & $\%$ \\
\hline 1 & Less & 52 & 27,5 \\
\hline \multirow[t]{2}{*}{2} & Low & 137 & 72,5 \\
\hline & Total & 189 & 100 \\
\hline
\end{tabular}

Source: Primary Data (processed), 2020

Table 9 shows that the majority of respondents had good performance at $72.5 \%$.

\subsection{Bivariate Analysis}

Bivariate analysis was carried out to determine the relationship between compensation variables $\left(\mathrm{X}_{1}\right)$, leadership style $\left(\mathrm{X}_{2}\right)$, work discipline $\left(\mathrm{X}_{3}\right)$ and application of sanctions $\left(\mathrm{X}_{4}\right)$ with performance (Y) for Aceh Provincial Health Office employees using the chi square test, the test results were as follows: 
a. Relationship of Compensation (X1) with Performance (Y) for Aceh Provincial Health Office Staff

Table 10. Relationship between Compensation $\left(\mathrm{X}_{1}\right)$ and Performance

(Y) for Aceh Provincial Health Office Staff

\begin{tabular}{|c|c|c|c|c|c|c|c|c|c|}
\hline \multirow{3}{*}{ No. } & \multirow{3}{*}{ Compensation } & \multicolumn{4}{|c|}{ The performance } & \multicolumn{2}{|c|}{ Total } & \multirow{3}{*}{$\alpha$} & \multirow{3}{*}{$\begin{array}{l}p \\
\text { value }\end{array}$} \\
\hline & & \multicolumn{2}{|c|}{ Less } & \multicolumn{2}{|c|}{ Good } & \multirow{2}{*}{ f } & \multirow{2}{*}{$\%$} & & \\
\hline & & $\mathbf{f}$ & $\%$ & $\mathbf{f}$ & $\%$ & & & & \\
\hline 1. & Unsuitable & 37 & 35,2 & 68 & 64,8 & 105 & 100 & \multirow{2}{*}{0,05} & \multirow{2}{*}{0,013} \\
\hline 2. & Suitable & 15 & 14,3 & 69 & 82,1 & 84 & 100 & & \\
\hline \multicolumn{2}{|c|}{ Total } & 52 & 27,5 & 137 & 72,5 & 189 & 100 & & \\
\hline
\end{tabular}

Table 10 shows that of the 105 respondents who stated that compensation was not appropriate it turned out that $64.8 \%$ of their performance was good and of 84 respondents who said compensation was in fact $82.1 \%$ of their performance was good. Chi square test results obtained $\mathrm{p}$ value $=0.013(\mathrm{P} \leq 0.05)$ so that it can be concluded that there is a relationship of compensation $\left(\mathrm{X}_{1}\right)$ with Performance $(\mathrm{Y})$ for Aceh Provincial Health Office Staff.

b. Relationship between Leadership Style $\left(\mathbf{X}_{2}\right)$ and Performance (Y) for Aceh Provincial Health Office employees

Table 11. Relationship between Leadership Style $\left(\mathrm{X}_{2}\right)$ and Performance $(\mathrm{Y})$ for Aceh Provincial Health Office Staff

\begin{tabular}{|c|c|c|c|c|c|c|c|c|c|}
\hline \multirow{3}{*}{ No. } & \multirow{3}{*}{ Leadership Style } & \multicolumn{4}{|c|}{ The performance } & \multicolumn{2}{|c|}{ Total } & \multirow{3}{*}{$\alpha$} & \multirow{3}{*}{$\begin{array}{l}p \\
\text { value }\end{array}$} \\
\hline & & \multicolumn{2}{|c|}{ Less } & \multicolumn{2}{|c|}{ Good } & \multirow{2}{*}{$\mathbf{f}$} & \multirow{2}{*}{$\%$} & & \\
\hline & & $\mathbf{f}$ & $\%$ & $\mathbf{f}$ & $\%$ & & & & \\
\hline 1. & Unsuitable & 22 & 43,1 & 29 & 56,9 & 51 & 100 & \multirow{2}{*}{0,05} & \multirow{2}{*}{0,006} \\
\hline 2. & Suitable & 20 & 21,7 & 108 & 78,3 & 138 & 100 & & \\
\hline Tota & & 52 & 27,5 & 137 & 72,5 & 189 & 100 & & \\
\hline
\end{tabular}

c. Relationship of Work Discipline $\left(\mathrm{X}_{3}\right)$ with Performance (Y) for Aceh Provincial Health Office employees

Table 12. Relationship of Work Discipline $\left(\mathrm{X}_{3}\right)$ with Performance (Y) for Aceh Provincial Health Office Staff

\begin{tabular}{|c|c|c|c|c|c|c|c|c|c|}
\hline \multirow{3}{*}{ No. } & \multirow{3}{*}{ Work Discipline } & \multicolumn{4}{|c|}{ The performance } & \multicolumn{2}{|c|}{ Total } & \multirow{3}{*}{$\alpha$} & \multirow{3}{*}{$\begin{array}{l}p \\
\text { value }\end{array}$} \\
\hline & & \multicolumn{2}{|c|}{ Less } & \multicolumn{2}{|c|}{ Good } & \multirow{2}{*}{$\mathbf{f}$} & \multirow{2}{*}{$\%$} & & \\
\hline & & f & $\%$ & $\mathbf{f}$ & $\%$ & & & & \\
\hline 1. & Less Discipline & 27 & 42,9 & 36 & 76,1 & 63 & 100 & \multirow{2}{*}{0,05} & \multirow{2}{*}{0,002} \\
\hline 2. & Discipline & 25 & 19,8 & 101 & 80,2 & 126 & 100 & & \\
\hline \multicolumn{2}{|c|}{ Total } & 52 & 27,5 & 137 & 72,5 & 189 & 100 & & \\
\hline
\end{tabular}

Source: Primary Data (processed), 2020 
Table 12 shows that of the 63 respondents who said they lack discipline, $76.1 \%$ performed well and from 128 respondents who said they were disciplined, $80.2 \%$ performed well. Chi square test results obtained $p$ value $=0.002(\mathrm{P} \leq 0.05)$ so that it can be concluded that there is a relationship of work discipline (X3) with Performance (Y) in Aceh Provincial Health Office Staff.

\section{d. Relationship between the Implementation of Sanctions $\left(\mathrm{X}_{4}\right)$ and Performance (Y) for Aceh Provincial Health Office employees}

Table 13. Relationship between the Implementation of Sanctions $\left(\mathrm{X}_{4}\right)$ and Performance (Y) for Aceh Provincial Health Office Staff

\begin{tabular}{|c|c|c|c|c|c|c|c|c|c|}
\hline \multirow{3}{*}{ No. } & \multirow{3}{*}{$\begin{array}{l}\text { Application of } \\
\text { Sanctions }\end{array}$} & \multicolumn{4}{|c|}{ Kinerja } & \multicolumn{2}{|c|}{ Total } & \multirow{3}{*}{$\alpha$} & \multirow{3}{*}{$\begin{array}{l}p \\
\text { value }\end{array}$} \\
\hline & & \multicolumn{2}{|c|}{ Less } & \multicolumn{2}{|c|}{ Good } & \multirow{2}{*}{$\mathbf{f}$} & \multirow{2}{*}{$\%$} & & \\
\hline & & $\mathbf{f}$ & $\%$ & $\mathbf{f}$ & $\%$ & & & & \\
\hline 1. & There is no & 23 & 39,7 & 35 & 60,3 & 58 & 100 & \multirow{2}{*}{0,05} & \multirow{2}{*}{0,021} \\
\hline 2. & There & 29 & 22,1 & 102 & 77,9 & 131 & 100 & & \\
\hline Tota & & 52 & 27,5 & 137 & 72,5 & 189 & 100 & & \\
\hline
\end{tabular}

Source: Primary Data (processed), 2020

Table 13 shows that of the 58 respondents who stated there was no application of sanctions it turned out that $60.3 \%$ of their performance was good and of the 131 respondents who stated that there were applications of sanctions it turned out that $77.9 \%$ of their performance was good. Chi square test results obtained $\mathrm{p}$ value $=0.021(\mathrm{P} \leq 0.05)$ so that it can be concluded that there is a relationship between the application of sanctions $\left(\mathrm{X}_{4}\right)$ with Performance (Y) for Aceh Provincial Health Office Staff.

\subsection{Multivariate Analysis}

The multivariate analysis used was multiple logistic regression tests, this test was carried out to find out which factors were the most dominant influencing the performance of the Aceh Provincial Health Office Staff. The results of the study can be seen in the following table:

Table 14. Logistic Regression

\begin{tabular}{lcc} 
Variable & p-value & OR \\
\hline Work Discipline $\left(\mathrm{X}_{3}\right)$ & 0,005 & 2,658 \\
Compensation $\left(\mathrm{X}_{1}\right)$ & 0,029 & 2,225 \\
Application of Sanctions $\left(\mathrm{X}_{4}\right)$ & 0,019 & 2,309 \\
\hline
\end{tabular}

Source: Primary Data (processed), 2020

Table 14 shows that the variables included in the multiple logistic regression test are compensation $\left(\mathrm{X}_{1}\right)$, work discipline $\left(\mathrm{X}_{3}\right.$ and application of sanctions $\left(\mathrm{X}_{4}\right)$ because in the candidate test the value of $\mathrm{p}<0.25$, while leadership style variables do not meet the requirements to be included in Multiple logistic regression test The test results show that there is a relationship between compensation $\left(\mathrm{X}_{1}\right)$, work discipline $\left(\mathrm{X}_{3}\right.$ and application of sanctions $\left(\mathrm{X}_{4}\right)$ with the performance of Aceh Provincial Health Service Employees $(\mathrm{P} \leq 0.05)$, wherein the work discipline variable is the most variable dominantly affects the performance of Aceh Provincial Health Service Employees $(p=0.005)$ and an OR value of 2.658 which 
means that employees who lack discipline are 2.6 times as likely to get poorer performance compared to disciplined employees.

\section{Conclusion}

There is a compensation relationship with the performance of Aceh Provincial Health Office employees $(p \leq 0.05)$. There is a relationship of leadership style with the performance of Aceh Provincial Health Office employees $(p \leq 0.05)$. There is a relationship of work discipline with the performance of Aceh Provincial Health Service employees $(p \leq 0.05)$. There is a relationship between the applications of sanctions with the performance of Aceh Provincial Health Office employees $(\mathrm{p} \leq 0.05)$.

\section{References}

Abdullah, M. (2014). Manajemen dan Evaluasi Kinerja Karyawan. Yogyakarta: Penerbit Aswaja Pressindo.

Afianto, I. U. (2017). engaruh Disiplin Kerja dan Komunikasi Organisasi Terhadap Kepuasan Kerja dan Kinerja Karyawan (Studi pada Karyawan Divisi Marketing PT. Victory International Futures Kota Malang). Administrasi Bisnis, 50(6).

Ajeng Kartika, S. (2014). Pengaruh Gaya Kepemimpinan Terhadap Kinerja Karyawan Dengan Motivasi Kerja Sebagai Variabel Moderating. Universitas Muhammadiyah Surakarta.

Ariyan, R. I. (2016). Pengaruh Gaya Kepemimpinan dan Loyalitas Karyawan Terhadap Kinerja Karyawan di Rumah Sakit Islam Hidayatullah Yogyakarta. Jurnal Medicoeticolegal dan Manajemen Rumah Sakit.

Arsela, B. (2017). Analisis Faktor- Faktor yang Mempengaruhi Kinerja Pegawai Pada Rumah Sakit Urip Sumoharjo di Bandar Lampung. Universitas Lampung.

DinkesAceh. (2018). Laporan Kinerja. Banda Aceh: Dinas Kesehatan Provinsi Aceh.

Ilyas, Y. (2012). Kinerja, teori, penilaian dan penelitian. Jakarta: Pusat Kajian Ekonomi Kesehatan FKM Universitas Indonesia.

Joshi, M. (2013). Human Resource Management. Denmark: Venus Publishing.

Kemenkes. (2018). Laporan Kinerja Ditjen Kesehatan Masyarakat. Jakarta.

Kuswati, Y. (2020). The Effect of Motivation on Employee Performance. Budapest International Research and Critics Institute-Journal (BIRCI-Journal). P.995-1002

Moeheriono. (2014). Pengukuran Kinerja Berbasis Kompetensi. Jakarta: PT. RajaGrafindo Persada.

Nurcahyani, N. M. (2016). Pengaruh Kompensasi Dan Motivasi Terhadap Kinerja Karyawan Dengan Kepuasan Kerja Sebagai Variabel Intervening. Manajemen Unud.

Pattiasina, M. R. (2014). Pengaruh Kompetensi Sumber Daya Manusia Terhadap Kinerja Karyawan PT.Bank Tabungan Negara, Tbk. Kantor Cabang Manado. Administrasi Bisnis, 1-6.

Rahman, R. H. (2016). Analisis Pemberian Sanksi Dalam Menegakkan Disiplin Pegawai Negeri Sipil. Fakultas Ilmu Sosial Dan Ilmu Politik Unila.

Riniwati, H. (2011). Mendongkrak Motivasi dan Kinerja: Pendekatan Pemberdayaan SDM. Malang: UB Press.

Riyanda, M. (2017). Pengaruh Kompetensi Dan Disiplin Kerja Terhadap Kinerja Pegawai Pada Dinas Perizinan Kota Yogyakarta. Fakultas Ekonomi UNY. 
Rizki, M. S. (2016). Analisis Faktor-Faktor Yang Mempengaruhi Kinerja Pegawai Pada Dinas Kesehatan Kabupaten Kutai Timur. Sekolah Tinggi Ilmu Ekonomi Nusantara Kutai Timur, Kaltim, Indonesia.

Salla, S. T. (2017). Analisis Kinerja Dinas Kesehatan Kabupaten Mamberamo Tengah Pada Program Kesehatan Ibu Dan Anak. Universitas Hasanuddin.

Sanjaya, M. T. (2015). Pengaruh Disiplin Kerja Dan Motivasi Kerja Terhadap Kinerja Karyawan Pada Hotel Ros In Yogyakarta. Fakultas EkonomI UNY.

Saragih, S. (2011). The Effects of Job Autonomy on Work Outcomes: Self Efficacy as an Intervening Variable. Business Studi.

Sedarmayanti. (2016). Manajemen Sumber Daya Manusia Reformasi Birokrasi Dan Manajemen Pegawai Negeri Sipil. Bandung: PT. Refika Aditama.

Sunarcahya, P. (2017). Analisis Faktor-Faktor Yang Mempengaruhi Kinerja Pegawai di Lingkungan Dinas Kesehatan Kabupaten Alor, Nusa Tenggara Timu. Masters thesis, Universitas Terbuka.

Sutrisno, E. (2016). Manajemen Sumber Daya Manusi. Jakarta: Penerbit Kencana.

Usman, U. (2014). Analisis Kinerja Tenaga Kesehatan Pada Puskesmaslapadde Kota Parepare. Media Kesehatan Masyarakat Indonesia. 